UDC 519.876.2:336

https://orcid.org/0000-0003-2474-7697

\title{
T.V. NESKORODIEVA*
}

\section{FORMALIZATION METHOD OF THE FIRST LEVEL VARIABLES IN THE AUDIT SYSTEMS IT}

*Vasyl Stus Donetsk National University, Vinnytsia, Ukraine

Анотація. Статтю присвячено проблемі створення інформаційних технологій для систем підтримки прийняття рішень в аудиті. Проблема є актуальною, оскільки створювані IT повинні забезпечувати аналіз великих обсягів даних. При иьому аналіз повинен бути інваріантний щодо особливостей економіко-виробничої діяльності підприсмства і його системи обліку. Відзначено, щзо дані характеризують підприємство як об'єкт аудиту і характеризуються глобальною багаторівневою ієрархічною структурою різнорідних, багатофакторних, багатофункиіональних зв'язків, взаємозалежностей і взаємодій його підсистем з IT контролю, обліку, управління, ведення бізнесу, з іншими IT і системами у структурі інформаиійної системи національної економіки. Відзначається, щзо для створення IT, яка відповідає даним вимогам, у попередніх роботах автора запропонована методика узагальнено-множсинного відображення даних аудиту. Також для підсистеми нижнього рівня виконана постановка двох завдань. У даній роботі розглядається проблема формалізащії змінних першого рівня для задач підсистем аудиту стандартів бухгалтерського обліку. Запропоновано метод формалізаиї змінних, інваріантний щодо характеристик підприємства, типів об'єктів, операиій обліку і відносин відповідності між ними. Метод заснований на формалізачії відносин відповідностей характеристик об'єктів і операчій двох задач у вигляді графів відповідності. Також змінні структуровані по відношенню їх до рівнів, на яких здійснюється розрахунок відповідних узагальнених показників. Це дозволить проводити аналіз, взаємопов'язаний за рівнями. Методика ілюструється на прикладі першої локальної задачі розрахунків з постачальниками, яка формалізована у вигляді перевірки відображення множин даних «оплачено-отримано».

Ключові слова: метод формалізації змінних, інформачійна технологія, СППР аудиту.

Аннотация. Статья посвящена проблеме создания информащионных технологий для систем поддержки принятия решений в аудите. Проблема является актуальной, поскольку создаваемые ИТ должны обеспечивать анализ больших объемов данных. При этом анализ должен быть инвариантный относительно особенностей экономико-производственной деятельности предприятия $и$ его системы учета. Отмечено, что данные, характеризующие предприятие как объект аудита, характеризуются глобальной многоуровневой иерархичной структурой разнородных, многофакторных, многофункииональных связей, взаимозависимостей и взаимодействий его подсистем, $c$ ИТ контроля, учета, управления, ведения бизнеса, с другими ИТ и системами в структуре информационной системы национальной экономики. Отмечается, что для создания ИТ, отвечающей данным требованиям, в предыдущих работах автора предложена методика обобщенномножественного отображения данных аудита. Также для подсистемы нижнего уровня выполнена постановка двух задач. В данной работе рассматривается проблема формализации переменных первого уровня для задач подсистем аудита стандартов бухгалтерского учета. Предложен метод формализачии переменных, инвариантный относительно характеристик предприятия, типов объектов, операций учета и отношений соответствия между ними. Метод основан на формализачии отношений соответствий характеристик объектов и операџий двух задач в виде графов соответствия. Также переменные структурированы по отношению их к уровням, на которых осуществляется расчет соответствующих обобщенных показателей. Это позволит проводить анализ, взаимосвязанный по уровням. Методика иллюстрируется на примере первой локальной задачи расчетов с поставщиками, которая формализована в виде проверки отображения «оплачено-получено».

Ключевые слова: метод формализации переменных, информационные технологии, ИТ СППР aудита.

Abstract. The article is devoted to the problem of creating information technologies for decision support systems in auditing. The problem is relevant because the created IT must provide analysis of large 
amounts of data. This analysis should be invariant with respect to the features of the economic and production activities of the enterprise and its accounting system. It is noted that the data characterizing an enterprise as an audit object is characterized by a global multi-level hierarchical structure of heterogeneous, multi-factorial, multifunctional connections, interdependencies and interactions of its subsystems, from IT control, accounting, management, business, to other IT and systems in structure of the information system of the national economy. It is noted that to create IT conforming to these requirements in previous works, the author proposed a method of generalized-multiple display of audit data. This paper addresses the problem of formalizing first-level variables for the tasks of audit accounting standards. The proposed method of variables formalization, invariant with respect to the characteristics of the enterprise, types of objects, accounting operations and correspondence relations between them. The method is based on the formalization of relations of correspondences of the characteristics of objects and operations of two tasks in the form of correspondence graphs. The variables are also structured in relation to their levels at which the calculation of the corresponding generalized indicators is carried out. This will allow for the analysis of interrelated levels. The technique is illustrated by the example of the first local task of calculations with suppliers, which is formalized in the form test of display a "paid-received".

Keywords: variable formalization method, information technology, audit DSS.

DOI: 10.34121/1028-9763-2019-4-79-86

\section{Introduction}

Currently, the actual scientific and technical problem of information technologies in the financial and economic sphere is the analyze automation of large amounts of financial and economic information of enterprises stored and received online in databases of local and global computer systems in order to formulate recommendations in audit. For example, the effectiveness of IT business in reducing corruption is justified in [1]. In [2] considered the theoretical and practical issues related to the use of IT in auditing. The changes of the audit methodology that the complex computerization makes are determined.

The use of modern accounting and management systems in enterprises that are integrated into global, multi-level information computer network systems provides the potential for processing large amounts of data that are not fully utilized [3]. In [4], the architecture of the subsystems of external and internal audit of the Audit 4.0 system is presented, the implementation and operation of which is faced with the problem of processing large amounts of data. Also today, practical and scientific sources studying the problems and prospects for the development of auditing consider the possibility of adopting legislation that will use analytical evidence (in particular data inconsistencies) obtained when analyzing large amounts of data as a basis for judicial decisions without a documentary study of primary documents [5].

Speaking about the automation of analysis procedures, it should be noted that fraud detection methods based on the use of neural (probabilistic) network models, logistic regressions, decision trees, expert assessments, statistical data analysis methods are presented in the literature [69]. The use of these methods allows you to analyze individual indicators or identify abnormal values. Their use gives the result if certain conditions are met that depend on the properties of the indicator, i.e. they are not universal, which makes it difficult to use them in solving automation problems at all stages of an audit. This indicates that the topic of research devoted to the design of IT auditing is relevant.

\section{Literature analysis and problem statement}

When is designing an audit IT, it is necessary to assume the possibility of their application to the financial and economic data of enterprises of various industries, types of production, various organizational structures and accounting IT. Economic and production activities and enterprises IT are forming a complex socio-economic technical system. This system, as an audit object, is characterized by a global multi-level hierarchical structure of heterogeneous, multi-factor, multifunctional connections, interdependencies and interactions of its subsystems, from control IT, ac- 
counting, management, business, with other IT and systems in the structure of the information system of the national economy. At the same time, at each level, the data has a network structure. Modern methodology of applied systems analysis does not meet these requirements [10]. Consequently, there is the problem of developing a methodological basis for designing an audit IT.

In [11] state the necessity of attribute sampling verification of documents is justified even under conditions of full automation of accounting based on a statistical approach to the formation of an audit sample. The presented attribute sampling methodology allows determining the sample size and the upper limit of accuracy. However, the question remains about the testing methodology for each group of documents and interrelated groups of documents (successive operations). It is also indicated that due to the fact that business operations and primary documents are formed using programs, therefore, errors associated with the calculation of amounts are practically excluded. At the same time, testing should be applied in order to ascertain whether the facts of economic activity recorded in the database of the computer accounting program actually took place. However, the formal formulation of this task was not completed, as well as the task of identifying signs of the existence of economic activity facts that took place and were not taken into account in the database.

In [2], in the justification section of the technology of direct research of accounts, a list of problematic issues related to the use of a sampling method in auditing [2, p. 329]. It is also proposed to use the law of F. Benford "anomalous numbers" for a complete statistical study of records, provides 4 conditions of this law and examples of its practical application. Verification of these conditions requires additional software resources, since it must be applied to each indicator and it remains unclear what to do if these conditions are not met. Consequently, these analysis methods allow to automate only certain analysis procedures in auditing IT (for example, sampling) [11] or to conduct analytical procedures in special cases [11], do not take into account interrelations between indicators of groups of documents (records) [2-5] and are not universal for all indicators, making it difficult to automate the analysis based on them. That is, there is a problem of completeness, universality and complexity of analysis techniques IT.

In [5] it is indicated that the existing licensed software on the Ukrainian market allows to solve the following tasks: to automate a significant part of labor-intensive procedures, to plan and control staff time costs. However, considered audit IT are characterized by the following problems: lack of interrelated (by tasks and levels) analysis, feedback on its effectiveness and efficiency, optimization of analysis in accordance with the goals and limitations set by the decision maker, and dialogue by means of domain language during the task tasks and interpretation of analysis results.

Designing DSS IT in accordance with the method of generalized-multiple information display proposed in [11] requires the creation of a method for formalizing primary accounting information for the automated solution of prerequisites audit problems of Provisions (standards) of accounting. The first stage of creating the method is setting two types of local tasks of data analysis during the verification period [12]. The first local task is the definition of equivalent and nonequivalent sets when displaying data sets of operations among which are correspondence relations for accounting objects of one type. The second one is the definition of equivalent and nonequivalent subsets when displaying accounting data for sets of two types of objects for which there are correspondence relations for operations of one type.

To formulate a method for solving local problems, it is necessary to formulate a method for formalizing the variables of the primary accounting of economic and production activities that are invariant with respect to the features of operation and accounting of the enterprise. For this it is necessary to solve the following tasks.

Purpose of the article:

- create rules for determining correspondence between first-level accounting variables and characteristics of objects, operations, and correspondence relations between them; 
- form the rules for determining the input and output variables of local tasks.

In order of generality, the method is considered for the audit subsystem of the accounting rule "Completeness" for material expenses on first level, since, due to the dimensionality of the data, the types of relationships between them and the number of elementary primary accounting subsystems (PAS) is the most common and time-consuming task.

\section{Rules for determining the correspondence between first level variables and the character- istics of objects, operations, and correspondence relations between them}

These rules will be defined on the basis of the formalization of objects, operations and two type of the relations in the graphs of type $G_{1}$ and $G_{2}[12]$ :

$$
\begin{gathered}
G_{1}\left(e_{s}\right)=\left(V_{1}\left(e_{s}\right), R_{1}\left(e_{s}\right)\right), V_{1}\left(e_{s}\right)=\left(x_{s}, x_{s+1}, e_{s}\right), \\
R_{1}\left(e_{s}\right)=\left(r_{s}^{+}, r_{s}^{-}\left(n_{s+1}\right)\right), e_{s}\left(n_{s}\right) \in E_{s}, \\
G_{2}\left(x_{s+1}\right)=\left(V_{2}\left(x_{s+1}\right), R_{2}\left(x_{s+1}\right)\right), V_{2}\left(x_{s+1}\right)=\left(e_{s}, x_{s+1}, e_{s+1}\right), \\
R_{2}\left(x_{s+1}\right)=\left(r_{s}^{-}\left(n_{s+1}\right), r_{s+1}^{+}\left(n_{s+1}\right)\right), x_{s+1}\left(n_{s+1}\right) \in X_{s+1},
\end{gathered}
$$

where $G_{1}$ - graph of data correspondence relations of the interrelated operations to data of primary accounting object;

$V_{1}$ - set of graph vertices $G_{1}$;

$R_{1}$ - set of graph edges $G_{1}$;

$G_{2}$ - graph of data correspondence relations of the interrelated objects to the operation;

$V_{2}$ - set of graph vertices $G_{2}$;

$R_{2}$ - set of graph edges $G_{2}$;

$e$ - vertex characterizing data of primary accounting object;

$s$ - type of accounting object, which increase;

$x$ - vertex characterizing the operation data;

$k$ - number of operations;

$r^{+}$- the edge characterizing the operation compliance relation to the increasing of accounting object;

$r^{-}$- the edge characterizing the operation compliance relation to the reduction of accounting object;

$n$ - number of primary accounting subsystem.

For the account of the characteristics of each object $e_{s}$ on first level forms the primary subsystem, which is determined by the number $n_{s}$ and the date of the creation. Also, in this subsystem are specified the characteristics of all elements of the graph of type $G_{2}$, the vertex of which is the given object. Moreover, due to the existence of interrelations between these characteristics, one variable can be a characteristic of several objects (duality of the values of variables). Therefore, to formulate a method for formalizing the variables of the selected subtasks, we define a set of vectors of the subsystem variables in accordance with the structure of the graph of type $G_{2}$, which is invariant with respect to the features of functioning and accounting of the enterprise and takes into account the duality of the values of variables: 


$$
V\left(n_{s}\right)=\left\{\bar{e}, \bar{x}, \overline{r_{s}^{+}}, \overline{r_{s-1}^{-}}, \overline{e_{s-1}}, n_{s}, \text { data }\right\}, s=\overline{1,4}
$$

where $V$ - subsystem variable set;

$s$ - accounting object type variable;

$n$ - subsystem variable number,

$\overline{e_{s}}$ and $\overline{e_{s-1}}-$ characteristics vectors of vertices $e_{s}$ and $e_{s-1}$ of the graph $G_{2}$ respectively;

$\overline{x_{s}}$ - characteristics vector of the vertex $x_{s}$ of the graph $G_{2}$;

$\overline{r_{s}^{+}}$и $\overline{r_{s-1}^{-}}$- characteristics vectors of the edge $r_{s}^{+}$и $r_{s-1}^{-}$of the graph $G_{2}$ respectively;

data - date of creation subsystem.

The structure of the variables vectors is defined in (5) will be represented as sets of vectors of variables, according to the values of which primary accounting data can be structured and summarized at different accounting levels (without loss of generality, we assume that there are three levels in the system):

$$
\bar{z}=\left(\overline{z^{l}}, \overline{z^{m}}, \overline{z^{a}}\right), z \in\left\{e, x, r^{+}, r^{-}\right\}
$$

where $\overline{z^{l}}, \overline{z^{m}}, \overline{z^{a}}$ - characteristics for which data is structured at a lower, middle and upper level, respectively.

\section{Rules for determining variables of local tasks}

Let's perform the formalization of the variables of the first task. The vector of the input variables is formed by the indicators of operations from the set of variables of the subsystem $V\left(n_{s}\right)(5)$, which in the graph of type $G_{1}$ correspond to increase of the objects of the set $E_{s}$ and indicators of their compliance:

$$
\bar{X}=\left(\left(n_{s}, \overline{r_{s}^{+}}, \overline{x_{s}}\left(n_{s}\right), \operatorname{data}\left(n_{s}\right)\right), n_{s} \in N_{s}\right) .
$$

The vector of the output variables is formed by the indicators of operations from the set of variables of the subsystem $V\left(n_{s}\right)(5)$, which in the graph of type $G_{1}$ correspond to reductions of the objects of the set $E_{s}$ and indicators of their compliance:

$$
\bar{Y}=\left(\left(n_{s+1}, \overline{r_{s}^{-}}, \overline{x_{s+1}}\left(n_{s+1}\right), \operatorname{data}\left(n_{s+1}\right)\right), n_{s+1} \in N_{s+1}\right) .
$$

Let us determine the variables of the first task (7) and (8) on the example of the "Calculations with suppliers" subsystem. Data sets of the calculations with suppliers are recorded in the account $s=63$. Therefore, the subsystem of calculations with suppliers denote $E_{63}$. Accordingly, the variables of subsystems of the operations accounting type $x_{1}$ - payment of the supplier's invoice define a set of input variables $\overline{X_{63}}$. Variables of subsystems of the operations accounting type $x_{2}$ - receipt of raw materials from the supplier define a set of output variables $\overline{Y_{63}}$ respectively.

The values of the input variables $\overline{X_{63}}$ during the period $T$ determine the corresponding set $X$. The values of the output variables $\overline{Y_{63}}$ during the period $T$ make up the set $Y$. Then, according to the structure of the first level subsystem, the structure of the sets of input and output data will be represented as a set of the elementary subsystems data: 


$$
\begin{gathered}
N=\left\{n=n\left(e_{1}\right): \operatorname{data}(n) \in T\right\}, \\
X=\{P O(n): n \in N\}, \\
\mathrm{M}=\left\{m=n\left(e_{2}\right): \operatorname{data}(m) \in T\right\}, \\
Y=\{W B(m): m \in \mathrm{M}\},
\end{gathered}
$$

where $n$ and $N$ - number and set of the numbers of the elementary account subsystems of the input data;

$m$ and $\mathrm{M}-$ number and set of the numbers of the elementary account subsystems of the output data;

data - creation date of the elementary account subsystem;

$P O$ и $W B$ - subsets of the input and output data of the elementary accounting subsystems, respectively.

The vector of input variables includes number $n$ and indicators of the $P O$ :

$$
\bar{X}=\left(\left(n, \delta_{d}, p_{d}, \Theta_{d},\left(v_{S_{d}}, c_{S_{d}}, \delta_{S_{d}}\right), s_{d} \in \Theta_{d}, \operatorname{data}_{d}\right), n \in N\right),
$$

where the variables are defined in tab. 1 ( 1 column).

The vector of output variables includes the waybill number $m, l-P O$ number which regards to this waybill and indicators of the waybill. Therefore, the PO number $l$ is the image of the waybill number $m$, under displaying $\varepsilon$, which for this subsystem we call "received-paid":

$$
l=\varepsilon(m),
$$

where $\varepsilon$ - displaying the PAS number of the output data to the PAS number of the input data.

Then the vector of output accounting variables has the appearance:

$$
\bar{Y}=\left(\left(m, l, \Theta_{k}, \delta_{k}, p_{k},\left(v_{S_{k}}, c_{S_{k}}, \delta_{S_{k}}\right), s_{k} \in \Theta_{k}, \operatorname{data}_{k}\right), m \in \mathrm{M}\right),
$$

where $l-P O$ number which regards to the waybill with the number $m$, the remaining variables are defined in table. 1 ( 2 column).

Table 1 - Account variables of the calculations with suppliers

\begin{tabular}{|c|c|c|c|}
\hline \multicolumn{2}{|c|}{ Input variables } & \multicolumn{2}{c|}{ Output variables } \\
\hline $\begin{array}{c}\text { designation } \\
x_{63}^{i}\end{array}$ & name & $\begin{array}{c}\text { designation } \\
y_{63}^{j}\end{array}$ & name \\
\hline$d$ & $\begin{array}{c}\text { operation type (payment of } \\
\text { the supplier's invoice) }\end{array}$ & $k$ & $\begin{array}{c}\text { operation type (receipt of raw ma- } \\
\text { terials from the supplier) }\end{array}$ \\
\hline$p_{d}$ & $\begin{array}{c}\text { supplier to whom payment } \\
\text { is transferred }\end{array}$ & $p_{k}$ & $\begin{array}{c}\text { supplier who supplied the raw } \\
\text { materials }\end{array}$ \\
\hline$s_{d}$ & $\begin{array}{c}\text { type of the paid raw mate- } \\
\text { rials }\end{array}$ & $s_{k}$ & type of the obtained raw materials \\
\hline$\Theta_{d}$ & set of paid raw materials & $\Theta_{k}$ & set of the obtained raw materials \\
\hline
\end{tabular}


Continuation of table 1

\begin{tabular}{|c|c|c|c|}
\hline$q_{d}$ & $\begin{array}{l}\text { the number of types of } \\
\text { paid raw materials }\end{array}$ & $q_{k}$ & $\begin{array}{l}\text { the number of types of raw materi- } \\
\text { als obtained }\end{array}$ \\
\hline$v_{s_{d}}$ & $\begin{array}{l}\text { amount of paid raw mate- } \\
\text { rials } s_{d}\left(s_{d} \in \Theta_{d}\right)\end{array}$ & $v_{s_{k}}$ & $\begin{array}{l}\text { amount of raw materials obtained } \\
\qquad s_{k}\left(s_{k} \in \Theta_{k}\right)\end{array}$ \\
\hline$c_{s_{d}}$ & $\begin{array}{l}\text { price of the paid raw mate- } \\
\text { rials } s_{d}\left(s_{d} \in \Theta_{d}\right)\end{array}$ & $c_{s_{k}}$ & $\begin{array}{l}\text { price of the obtained raw materials } \\
\qquad s_{k}\left(s_{k} \in \Theta_{k}\right)\end{array}$ \\
\hline$\delta_{s_{d}}$ & $\begin{array}{l}\text { cost of the paid raw mate- } \\
\text { rials } s_{d}\left(s_{d} \in \Theta_{d}\right)\end{array}$ & $\delta_{s_{k}}$ & $\begin{array}{l}\text { cost of the raw materials obtained } \\
\qquad s_{k}\left(s_{k} \in \Theta_{k}\right)\end{array}$ \\
\hline$\delta_{d}$ & $\begin{array}{l}\text { cost of the paid raw mate- } \\
\text { rials of the set } \Theta_{d}\end{array}$ & $\delta_{k}$ & $\begin{array}{l}\text { cost of the obtained raw materials } \\
\text { of the set } \Theta_{k}\end{array}$ \\
\hline
\end{tabular}

Since each PAS number of the output data corresponds to a single PAS number of the input data, this correspondence of numbers for the period $T$ spawns the display of sets of numbers PAS output data to numbers PAS input data:

$$
\mathrm{M} \stackrel{\varepsilon}{\longrightarrow} L
$$

where $\varepsilon$ - displaying the PAS number of the output data to the PAS number of the input data;

$L-$ set of PAS number of the input data in output data PAS.

According to the relation of conform $G_{2}$ get us perform the classification of variables of subsystem (9) and (10) in accordance with the structure of the vector of input variables invariant with respect to the features of the enterprise (15) take the form:

$$
\begin{gathered}
\bar{x}_{1}(n)=\left(\overline{x_{1}^{l}}, \overline{x_{1}^{m}}, \overline{x_{1}^{a}}\right), n \in N, \\
\overline{x_{1}^{l}}=\left(n,\left(s_{d}, v_{S_{d}}, c_{S_{d}}, \delta_{S_{d}}\right), s_{d} \in \Theta_{d}, \text { data }\right), \overline{x_{1}^{m}}=\left(p_{d}, q_{d}\right), \overline{x_{1}^{a}}=\left(\delta_{d}\right),
\end{gathered}
$$

where $r_{1}^{+}$- relation of conformity to increase object $e_{1}$ (calculations with suppliers);

$$
\overline{r_{1}^{+(l)}}=\left(n_{1}\right), \overline{r_{1}^{+(m)}}=\left(p_{d}\right), \overline{r_{1}^{+(a)}}=(d),
$$

where $d$ - the relationship to the increase of the accounting object;

$p_{d}$ - type of supplier to whom payment is transferred;

$x_{2}$ - receipt of raw materials from the supplier;

$$
\begin{gathered}
\overline{x_{2}}(m)=\left(\overline{x_{2}^{l}}, \overline{x_{2}^{m}}, \overline{x_{2}^{a}}\right), m \in \mathrm{M} ; \\
\overline{x_{2}^{l}}=\left(m,\left(s_{k}, v_{S_{k}}, c_{S_{k}}, \delta_{S_{k}}\right), s_{k} \in \Theta_{k}\right), \overline{x_{2}^{m}}=\left(p_{k}, q_{k}\right), \overline{x_{2}^{a}}=\left(\delta_{k}\right) ;
\end{gathered}
$$

$r_{1}^{-}-$relation of conformity to reduction object $e_{1}$ (settlements with suppliers);

$$
\overline{r_{2}^{-(l)}}=(l), \overline{r_{2}^{-(m)}}=\left(p_{d}\right), \overline{r_{2}^{-(a)}}=(k) ;
$$

$k$ - relation of conformity to reduction object (cash).

Formulas (15)-(20) determine the tools for taking into account the special features of the enterprise accounting when importing data into the audit system. 
Input vector values $\bar{X}$ (13) for the period $T$ determine the set of multi-dimensional input data subsystem:

$$
X=\left\{\left(n, p_{d}(n), \Theta_{d}(n), \delta_{d}(n),\left(v_{S_{d}}(n), c_{S_{d}}(n), \delta_{S_{d}}(n)\right), s_{d} \in \Theta_{d}\right), n \in N\right\} .
$$

The values of the vector of output variables $\bar{Y}$ (10) for the period $T$ determine the set of multi-dimensional output data of the subsystem:

$$
Y=\left\{\left(m, l, p_{k}(m), \Theta_{k}(m), \delta_{k}(m),\left(v_{S_{k}}(m), c_{S_{k}}(m), \delta_{S_{k}}(m)\right), s_{k} \in \Theta_{k}\right), m \in M\right\},
$$

where variables are defined in table 1 (column 2).

\section{Conclusion}

The proposed method of the variable formalization is invariant with respect to the characteristics of the enterprise, the type of accounting object, the type of accounting transaction and the relationship between them. It is common for two types of local tasks of the audit system. This allows to use this method to create tools for the account of the special features of the enterprise at the stages of solving two local tasks regarding these objects and accounting operations of any kind. This technique is an element of the methodology for formalizing information in audit systems.

\section{REFERENCE}

1. Hu X. Effectiveness of information technology in reducing corruption in China. Electronic Library. 2015. Vol. 33, N 1. P. 52-64.

2. Ivakhnenkov S. Information technology of the audit and internal control in the context of world integration. Zhytomyr: PE "Ruta", 2010. 356 p.

3. Kirkos E., Spathis C., Manolopoulos Y. Data mining techniques for the detection of fraudulent financial statement. Expert Syst. Appl. 2007. Vol. 32, N 4. P. 995-1003.

4. Dai J., Vasarhelyi M. Imagineering Audit 4.0. Journal of Emerging Technologies in Accounting. 2016. Vol. 13, N 1. P. 1-15.

5. Jaremko S.A., Kovalenko V.V. Investigation of the problems of implementation of modern information audit systems in the control and audit activity. Computer integrated technology-based science review. Lutsk. 2104. Vol. 14. P. 179-182.

6. Jarrod W., Bhattacharya M., Islam R. Intelligent Financial Fraud Detection Practices: a comprehensive review. Computers \& Security. 2016. Vol. 57. P. 47-66.

7. Chi-Chen L., Chiu An-An., Yan H. Detecting the financial statement fraud: The analysis of the differences between data mining techniques and experts' judgments. Knowledge-Based Systems. 2015. N 89. P. 459-470.

8. Mohiuddin A., Mahmooda A., Rafiqul I. A survey of anomaly detection techniques in financial domain. Future Generation Computer Systems. 2016. N 55. P. 278-288. URL: https://doi.org/10.1016/j.future. 2015.01.001.

9. Bjujulj A. SPSS: The art of information processing. Analysis of statistical data and restoration of hidden patterns. Saint Petersburg: DiaSoftUP, 2005. 608 p.

10. Zhurovs'kyy M., Pankratova N. System Analysis: Methodology. Problems Applications: monograph 2nd ed., revised and supplemented. K.: Naukova dumka, 2016. 726 p.

11. Neskorodieva T. Rules and components of a generalized-multiple information display method in the express analysis subsystem of the audit decision support system. Bulletin of the NTU "KhPI". Series: System Analysis, Management and Information Technology. 2017. Vol. 55, N 1276. P. 31-38.

12. Neskorodieva T. Formulation of elementary tasks of audit subsystems of accounting provisions precondition DSS IT. Advanced Information Systems. 2019. Vol. 3, N 1. P. 48-53. 